\title{
Microbial Enzymes Based Technologies for Bioremediation of Pollutions
}

\author{
Gity Behbudi, Khadije Yousefi*, Yasin Sadeghipour \\ Biotechnology Research Center, Shiraz University of Medical Sciences, Shiraz, Iran.
}

Received: 19/12/2020

Accepted: 24/01/2021

Published: 20/06/2021

\begin{abstract}
Environmental pollution comes from a variety of sources. With the development of human civilization, the development of technology, and the increasing population, the world is now facing environmental pollution. Since environmental health has a direct effect on human health, therefore environmental protection is one of the most essential human problems. Removal of pollutants is a significant issue that, if not paid enough attention to, the next generation will face serious problems. Chemical and biological methods can be used to remove contaminants, but since the use of chemical methods will result in wastes that can cause contamination, the use of biological treatment methods such as bioremediation is a better and less dangerous to remove contaminants. In the bioremediation process, fungi or bacteria and their enzymes are used to clean and purify pollution. In this waste management technique living organisms or their enzymes uses to remove or neutralize contaminants. Mechanisms of enzymes that related bioremediation such as hydrolases and oxidoreductases have been widely studied. This chapter investigates information on the microbial enzymes from different microorganisms involved in the biodegradation of a broad range of pollutants.
\end{abstract}

Keywords: Microbial enzymes, Bioremediation, Pollution, Environment

\section{Introduction}

The quality of life on earth is directly related to the overall quality of the environment. Unfortunately, with development in technology, science, and industry, a large number of nuclear waste and raw sewage is dumped or let out into the environment and therefore causing an earnest difficulty for human survival on earth. The advancement of science and the more significant presence of industries in life have caused entrance much pollution in the distribution environment. Disposal of waste and pollution in the traditional way causes a lack of space for the subsequent disposal of the rest of the waste. In the past, garbage was traditionally drilled in the pit and then disposed of with waste. This method of waste disposal was faced with a lack of space each time the waste was discharged. New waste disposal technology also uses chemical decomposition and incineration at high temperatures, such as UV oxidation methods and base-catalyzed dechlorination. Although these methods can be useful in reducing pollutants, they still have problems [1-3]. It is essential to control the types of pollutants and prevent the diseases' spread [4]. Any substance that inadvertently enters the environment is known to be a pollutant. The damage that pollutants cause to the environment through natural or human resources is pollution. Human societies, due to their increasing activities, cause water, air, and soil pollution, which somehow enter the pollution to human food chain. Urbanization and industrialization are also spreading a lot, which causes a lot of pollutions [5]. Environmental pollution, including soil and water pollution, is caused by industrial and agricultural processes that pose serious risks to human health and have devastating consequences for the ecosystem [6-8].

Enzymes are the materials that can change the reactions rate and reaction activation energy; however, they do not present in the reaction. Enzymes can be active in wide ranges of environmental conditions changes e.g., changes in $\mathrm{pH}$ and temperature [9]. Enzymes, due to their catalytic role, have an essential position in metabolic and biochemical reactions. Among biological agents, enzymes have a remarkable ability to detoxify and effectively convert contaminants because they can break down contaminants very quickly. In general, enzymatic methods promise to remove contaminants in the form of biodegradation [10-13]. There are many microbes such as bacteria, fungi, and yeast can produce enzymes. Microbial enzymes that produce by microorganisms have high performance, efficiency, and easy way of production. Microorganisms are the primary source of enzymes, because to reinforce enzyme production, genetic manipulation on microorganisms cells such as bacteria cells can occur [14-16]. One of the ways to control pollution is bioremediation. Bioremediation is a process that uses microorganisms or plants or their enzymes for treating the pollutions $[17,18]$. Only some pollutants are biodegradable, and bioremediation is a process in which biological destruction occurs with the interaction between microorganisms and pollutions. For the bioremediation process, the environmental conditions should be suitable for the growth of microbes, and enough nutrients accessible for microbes. The aim of the chapter is to express the use of modern methods of enzyme microbes to treat contamination. Enzymatic microbes are biocompatible and biodegradable contaminants

\section{Enzymes}

Enzymes are the categories of biological catalysts that have at least one polypeptide section [1]. The use of enzymes for eliminating contamination, resolves many of the disadvantages

\footnotetext{
*Corresponding author: Khadije Yousefi, Biotechnology Research Center, Shiraz University of Medical Sciences, Shiraz, Iran. Email:Khadije.yousefi@gmail.com
} 
posed by eliminating contamination by microorganisms. Also, the use of enzymes has superiority rather than traditional methods and microbial remediation. Microbial metabolism inhibitors that affect the inhibition of microbes do not affect the inhibition of enzymes. Enzymes could continue to function under severe and restrictive conditions imposed on microbial activity. Enzymes can also affect deficient concentrations of pollutants and are active in the presence of antimicrobial agents. Microorganisms prefer to destroy contaminants that decompose quickly, but enzymes are smaller than microorganisms, so they have more movement and can destroy contaminants with a high degree of hardness. Some of the enzymes such as hydrolases, dehalogenases, transferases, and oxidoreductases involved in refining pollution [10, 19, 20]. For example, esterases, haloalkanes, and glutathiones are in the categories of hydrolases, dehalogenases, transferases, and oxidoreductases, respectively. Esterases are in the category of hydrolases enzymes, that they can form ester bonds by catalyzing the cleavage. Esterases have the ability to degrade natural compounds or industrial pollutants, due to stereoselective action [21]. Haloalkanes are in the category of dehalogenases enzymes. These enzymes can catalyze halogenated aliphatic pollutants such as chlorine, bromine, and iodine, and convert to alcohol, halide, and a hydrogen ion. Haloalkanes have industrial and bioremediation applications [22-24]. Glutathiones are in the category of transferases enzymes and found in the cytosol. These enzymes have a wide range of abilities in induction biological stress, and they are involved in antioxidant attacks $[25,26]$. Oxygenases belong to the oxidoreductases group of enzymes. These enzymes can transfer oxygen from an oxygen-containing molecular and could oxidize the substrates. Oxygenases can degrade or detoxification compounds [27-31]. According to Figure 1, enzyme have the polyelectrolyte wall; the molecule that must be degraded could be exposed to the polyelectrolyte wall and allowed to penetrate.

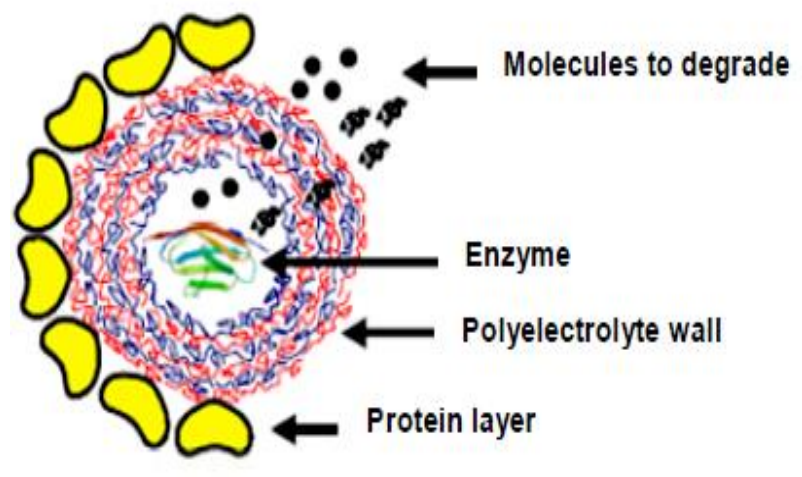

Figure 1: Degradation of molecules by enzymes [32]

Active sites of enzymes involved in catalytic processes; in other words, enzymes by creating covalent or noncovalent bonds, could involve in catalytic processes. Enzymes could involve in the bioremediation of pollutants by the biodegradation process. Enzymes could include in the six section that includes oxidoreductases, transferases, hydrolases, lyases, isomerases, and ligases. Oxidoreductases enzymes could change the place of electrons and protons from a transferor to a receptor. The transferases enzymes could transfer one of the functional groups from a transferor to a receptor. The hydrolases enzymes help for the splitting of bonds by water. The lyases enzymes could catalyze the split of bonds by removing them. Isomerase enzymes help for retuning of geometric or structural. Ligases enzymes help for joining each other of two molcules [1]. Mohsenzade et al. surveyed enzymatic activity in some fungi for application in bioremediation of pollution of petroleum. In this work, three enzymes include Catalase, Peroxidase, and Phenol Oxidase, were selected, and their activity checked in the fungal. The ability for bioremediation of fungal enzymes was surveyed on the soil of petroleum. Results show that enzymes of fungi had good resistance for the removal of pollutants. In other words, they had the good ability to grow petroleum pollutants. In the bioremediation process, they could decrease the number of pollutants. The highest enzymatic activity belonged to Aspergillus terreus fungi [33]. Redox enzymes have the ability to transmission pollutions in the infected sites; for example, chromate reductases are in categories of redox enzymes such as Pseudomonas putida and Escherichia coli that have the ability to catalyzing $\mathrm{Cr}$ (VI) to $\mathrm{Cr}$ (III), which has less solubility and toxicity. In the redox cycle, one of the electrons transfer to oxygen and could produces reactive oxygen species (ROS). The existence of ROS and oxidative stress, reduces contaminated chromium, and reduces pollution [34, 35]. Extracellular enzymes are the category of enzymes that are secreted by microbes. These enzymes can convert a composition from a tenacious mood to a more biodegradable state. Extracellular enzymes have the ability to increase the degradation rate [9]. Novotny et al. used Ligninolytic fungi as extracellular enzymes for bioremediation of water and soil pollutants. ligninolytic fungi's included Mn-dependent peroxidase, lignin peroxidase, and laccase that investigated for degradation of hydrocarbons, polychlorinated biphenyl mixture, and dyes. Results showed a high amount of Mndependent peroxidase could remove Reactive Orange 16 azo. Mn-dependent peroxidase, lignin peroxidase, and laccase could degraded soil pollution such as anthracene and pyrene. These enzymes have better efficiency in liquid media compared to soil media [4].

\subsection{Microbial enzymes}

It has been a long time that industrial product makers utilize microbial enzymes as the main catalysts to transport raw materials into end products [36]. Microbial enzymes act as biocatalysts and catalyze biochemical and metabolic reactions in an environmentally friendly manner. Microbial enzymes are known as special enzymes due to their various industrial and medical applications, having stability, owning catalytic role, and ease of production [37, 38]. Microbial enzymes have many advantages in comparison with chemical catalysts; for this reason, microbial enzymes, including very interesting biocatalysts that have been widely studied [39]. Microbial enzymes have applications in many areas, such as food production, pharmaceuticals, agriculture, fermentation, and chemical processes [40]. Microbial enzyme generation focuses on simple hydrolytic enzymes that can degrade natural polymers such as pectin, starches or proteins, starches. These enzymes include pectinases, proteases, and amylases. The microorganisms for further use of enzymes, the enzymes secreted into the nutrient medium. These extracellular enzymes for feeding the microorganisms, separate the huge molecules of the substrate into smaller molecules [41]. For example, oxidoreductases are the type of microbial enzymes which exist in microbes, plants, and animals. In enzyme Commission (EC), oxidoreductases category as EC 1 . These enzymes have the ability to exchanging of electrons between electron donor molecules and electron acceptors substrates. In this process, oxidative and reductive reactions occur and oxidizing and reducing materials could be active or transform [42]. These enzymatic reactions require the presence of electrons or 
hydride ions [43]. Oxidoreductases are transferred with cofactors such as heme groups; flavin group includes flavin mononucleotide and flavin adenine dinucleotide and metal ions $[43,44]$. Generally, oxidoreductases, that can produce smaller molecules, versus bacteria are reactive [45]. Cheriyan et al. investigated enzymatic bioremediation for cashew nut shell liquid contamination. In this work, oxidoreductases and proteases enzymes were used for bioremediation of cashew nut shell liquid (CNSL). Peroxidase enzymes reduced the color of the cashew nut shell liquid solution, and protease degraded the phenolic of solution [46]. As shown in Figure 2, there are different types of oxidoreductases include oxidases, dehydrogenases, and hydroxylases.

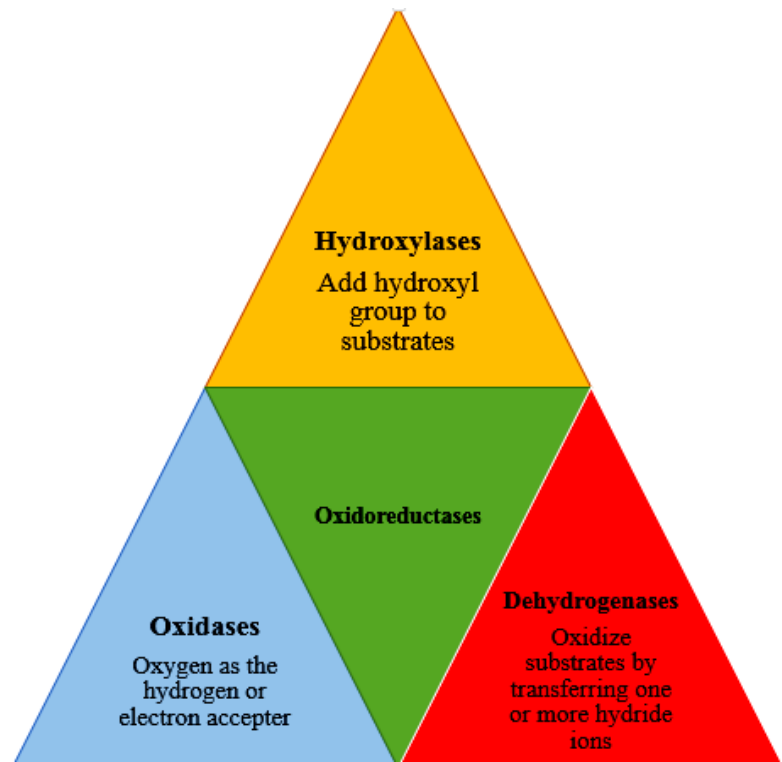

Figure 2: Types of oxidoreductases enzymes [42]

\subsubsection{Oxidases}

Oxidases can catalyze the reactions by using dioxygen molecules in the role of electron acceptor [47]. In other words, oxidases use molecular oxygen as an electron acceptor [48]. Oxidases use different materials such as metals and cofactors for transferring electrons. These materials include flavin or alcohol-based metals or amine oxidases [49].

\subsubsection{Dehydrogenases}

Dehydrogenase enzymes catalyze the reaction with coenzymes such as nicotinamide adenine dinucleotide (NAD) or nicotinamide adenine dinucleotide phosphate (NADP), flavin group, and flavin mononucleotide (FMN) [47]. All living microorganisms contain the dehydrogenase enzyme, which transports hydrogen atoms from organic transporters to electron acceptors substances [50].

\subsubsection{Hydroxylases}

Hydroxylases enzymes have active sites containing metal that can catalyze the reactions $[51,52]$. The metal in the activator role changes the oxidation state of the substrate. Iron metal is commonly used to change the oxidation state, and the metal also transmits its electrons through the electron transfer chain [52]. Iron metal can transfers oxygen to compound or form $\mathrm{OH}$ radicals [53]. In Table 1, application of oxidoreductases enzymes are shown

\section{Bioremediation}

Bioremediation is a process that occurs by using microorganisms that pollutants could transit or degrade into low-degree pollution. Bacterias, fungus, algae, and plants use in this method. In other words, enzymes of these microorganisms attack the pollutants and convert them to lowrisk pollutants $[1,58]$. In bioremediation after degradation of pollutions, the society of microorganisms reduced, and the presence of microorganisms don't create more pollutions [4]. Bioremediation is a new technology which can be used for treatment of a different group of environmental pollutants with other physical and chemical methods of treatment, simultaneously [59].

\begin{tabular}{|c|c|c|}
\hline Enzyme & Application & Ref \\
\hline 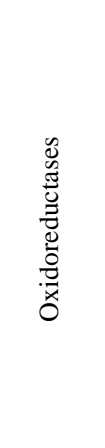 & $\begin{array}{l}\text { Biotransformation of lignocellulosic } \\
\text { biomass, Derivatization of carbohydrates, } \\
\text { Food industry, Environmental protection, } \\
\text { Synthesis of organic materials, Synthesis of } \\
\text { nanomaterials and polymers, Synthesis of } \\
\text { medicinal materials, Biocatalysts for } \\
\text { bio-based economy, Textile industry, } \\
\text { Cleansing applications, Biodegradation, } \\
\text { Biodetoxification and Biosensors and } \\
\text { decontamination, applications, } \\
\text { bioreportors, Medical Medical } \\
\text { Coenzymes regeneration, andunctionaliztion of } \\
\text { applications, Oxyfun } \\
\text { organic substrates }\end{array}$ & $\begin{array}{l}{[43,} \\
54-57]\end{array}$ \\
\hline
\end{tabular}

Zamanpour et al. investigated bioremediation and photolysis of enrofloxacin. Structured packing rotating biological contactor was designed and created as a biological setup. The removal rate reached a maximum of $70 \%$ only for the biological unit. Different concentrations of enrofloxacin were examined on the biological unit. At the starting point of the process removing of the drug were equal to $70 \%$, but by spending the time, it decreased to $40 \%$ [60]. The bioremediation process happens with the presence of microorganisms which this method has some advantages and disadvantages are tabulated in Table 2. In Figure 3 shown a bioremediation process that plants, bacteria, and fungi could remove pollutions and create green earth with a low amount of pollutions.

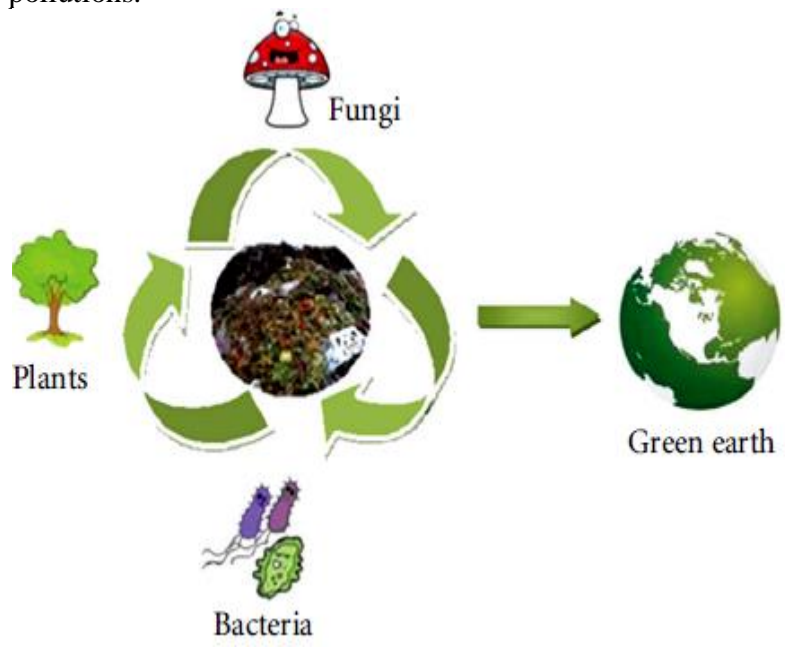

Figure 3: bioremediation process [1]

Ali et al. investigated the bioremediation of soils with crude oil. Desert soil $(17.3 \%$, w/w) was saturated with crude oil. Results after one month showed that 53-60\% of the oil was eliminated. After five months, $14-20 \%$ of the oil was eliminated. Microorganisms such bacteria's presented in a polluted site that could be act in oil saturation conditions [68]. 
Table 2: Advantages and Disadvantages of Bioremediation process $[1,4,61-67]$

\begin{tabular}{|c|c|}
\hline & $\begin{array}{l}\text { Low cost } \\
\text { Environmental friendly } \\
\text { Easy method } \\
\text { A safe method for the environment } \\
\text { Socially acceptable method } \\
\text { Combination with other treatment methods } \\
\text { Removing operating and transportation costs } \\
\text { Minimal disruption in the ecosystem } \\
\text { Madding directly on the site } \\
\text { Self-sustaining } \\
\text { Not producing waste } \\
\text { Having the capability to degrade many } \\
\text { Contaminants } \\
\text { Needing an average level of fund investiture }\end{array}$ \\
\hline & $\begin{array}{l}\text { Low speed of the process } \\
\text { Using special species of bacterias and fungi } \\
\text { Limited to biodegradable compounds } \\
\text { Hard to do in piloted field and difficult of implementing the } \\
\text { method on an industrial scale } \\
\text { Needing more efforts for training and education to general } \\
\text { success acceptance } \\
\text { Retransfer of pollutants previous stabilized by changing } \\
\text { geochemical and hydrological situations } \\
\text { Migration of probable pollutant and its transfer via the } \\
\text { environment } \\
\text { Required to process a control formalize for a long-term } \\
\text { conservation due to long time of bioremediation process } \\
\text { Needing more nutrients or oxygen for doing the bioremediation } \\
\text { process on clay soils } \\
\text { Destroying products and may creating products with more } \\
\text { toxicity } \\
\text { Limitation of the method to biodegradable products } \\
\text { Needing for essential site factors for achievement include } \\
\text { appropriate levels of nutrients and contaminants, suitable } \\
\text { environmental growth conditions, and the presence of } \\
\text { metabolically capable microbial populations } \\
\text { Complicated controlling volatile organic compounds (VOCs) in } \\
\text { an ex-situ process }\end{array}$ \\
\hline
\end{tabular}

\subsection{Microbial bioremediation}

Microbial bioremediation are a process that use spent biomass, enzymes, or microorganisms for removing environmental pollutions. Pollutants in the various environmental sections, always have contact with microorganisms due to the microorganisms' existence everywhere. Microbes allow the pollutant to be channeled into the normal microbial metabolic pathway for biotransformation and degradation. Microbes transform or break down the pollutants via their intrinsic metabolic processes with or without slight pathway modifications. In the bioremediation process, by using naturally occurring microbial catabolic capabilities, most of the synthetic compounds such as metals, radionuclides, polyaromatic hydrocarbons (PAHs), polychlorinated biphenyls (PCBs), and hydrocarbons (e.g., oil) can be accumulated, transform or degrade [19, 69]. Microbial bioremediation includes proseccos such as aerobic process, anaerobic process, and combination of these two methods. Cellules that need the oxygen molecules presence during the cellular processes named aerobic, and cellulose that do not require for the presence of oxygen molecules named anaerobic $[4,70]$. In figure 4, illustration how microbes, remove pollutions into the environment, is shown. According to this figure, microorganisms include microbes adsorb pollutions into their active cites and degrade the pollutions and convert them in other forms and finally remove the pollutions. The bioremediation process is a complicated method and depends on biological and environmental factors shown in Table 3. These factors detect the kinetics of degradation. Amount of humidity effects on the rate of pollutions metabolism.

\subsection{Bioremediation of hospital biomedical waste}

Hospital wastes like anatomic wastes, solid wastes, disposals, sharps, etc. are produced via different process occur in the hospitals such as research activities and immunization. These generated wastes can be harmful to human and contains infectious diseases if not administered with a suitable method. Bacterias have the ability to remediate liquid waste that maybe become a good option for remediation of medical waste [71, 72]. Hospital biomedical waste, which mainly consists of organic matter, can be amplified by microbial hydrolytic enzymes that have high potential. Bacteria capable of producing hydrolytic enzymes such as amylase, protease, and lipase, are needed to remove hospital contaminants [73]. In Figure 5 shown stages of bioremediation of hydrolytic bacteria isolated from medical waste. According to the figure, at first should choose the hydrolytic bacteria that has more ability to be used as a bioremediation agent [74].
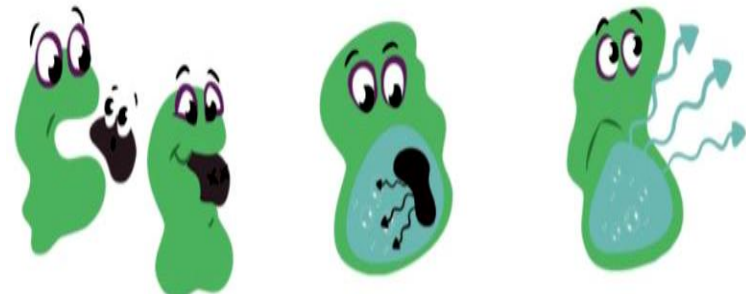

Figure 4: Bioremediation process [11]

Table 3: Effective factors on microbial bioremediation Occurring biodegradation process in optimal $\mathrm{pH}$ The optimum temperature for detection of the speed of bioremediation process

Amount of humidity that effecting on the rate of pollutions metabolism

Effect of soil structure on biodegradation factors and

adverse effect of moisture in the structure

Solubility in water

Availability of essential nutrients for microbial growth and biodegradation rate

Site Characteristics for detection of the horizontal and vertical amount of pollution

Redox potential

Amount of oxygen for reinforcement of hydrocarbon metabolism

Contaminant concentration

Type of microorganism

Type of pollutions

Geological and chemical conditions at polluted sites

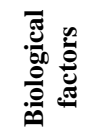

Mutation

Horizontal gene transfer

Enzyme activity

Interaction

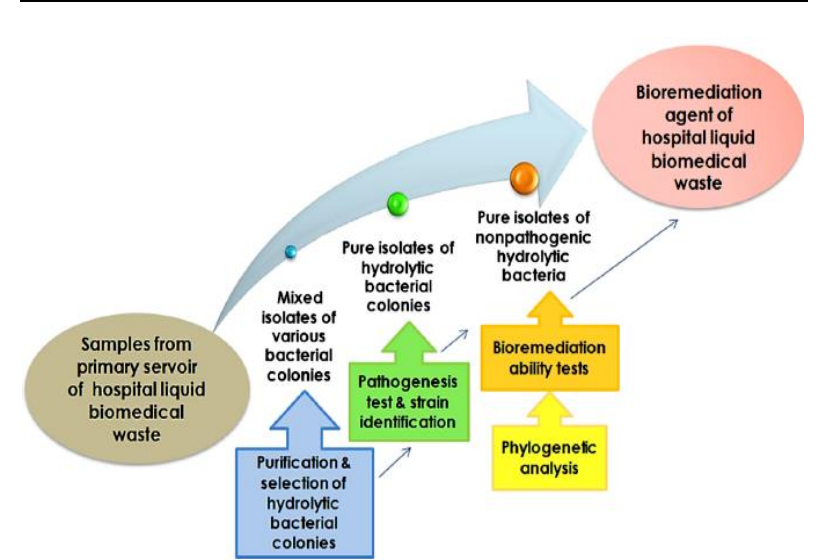

Figure 5: Bioremediation of hydrolytic bacteria isolated from medical waste [74] 


\section{Conclusion}

The pollution of water and soil created by petroleum hydrocarbons and industrial chemicals, is an essential matter in the whole world. Because of the high usage of mentioned materials, they are involved as environmental pollutions in numerous terrestrial and aquatic ecosystems. The use of bioremediation method for removing these pollutions, provides an economical and safe economic method to commonly used physical-chemical treatment. Physical and chemical technologies have high costs when using on a large scale. By utilizing the massive variety of metabolic pathways and biological activities presented by microorganisms, new strategies can be encountered. Using the activity of enzymes is an essential step in the utilization and degradation of pollutions. Many enzymes from plants, fungi, and bacteria have been reported to be involved in the biodegradation of toxic organic pollutants. Bioremediation is a nature- friendly biotechnology and cost-effective that is applied by microbial enzymes. The research activity in this field would help to develop advanced bioprocess technology to achieve new useful substances and reduce the toxicity of the pollutants.

\section{Ethical issue}

Authors are aware of, and comply with, best practice in publication ethics specifically with regard to authorship (avoidance of guest authorship), dual submission, manipulation of figures, competing interests and compliance with policies on research ethics. Authors adhere to publication requirements that submitted work is original and has not been published elsewhere in any language.

\section{Competing interests}

The authors declare that there is no conflict of interest that would prejudice the impartiality of this scientific work.

\section{Authors' contribution}

All authors of this study have a complete contribution for data collection, data analyses and manuscript writing.

\section{References}

1. Karigar CS, Rao SS. Role of microbial enzymes in the bioremediation of pollutants: a review. Enzyme research. 2011;2011.

2. Mousavi M, Hashemi A, Arjmand O, Amani AM, Babapoor A, Fateh MA, et al. Erythrosine adsorption from aqueous solution via decorated graphene oxide with magnetic iron oxide nano particles: kinetic and equilibrium studies. Acta Chimica Slovenica. 2018;65(4):882-94.

3. Behbudi G. Heavy Metal Removal Methods from Water and Wastewater: A Review Study. Environmental Health. 2020;6(2):145-60.

4. Novotný C̆, Svobodová K, Erbanová P, Cajthaml T, Kasinath A, Lang E, et al. Ligninolytic fungi in bioremediation: extracellular enzyme production and degradation rate. Soil Biology and Biochemistry. 2004;36(10):1545-51.

5. Manisalidis I, Stavropoulou E, Stavropoulos A, Bezirtzoglou E. Environmental and health impacts of air pollution: A review. Frontiers in public health. 2020;8.

6. Singh P, Singh VK, Singh R, Borthakur A, Madhav S, Ahamad A, et al. Bioremediation: a sustainable approach for management of environmental contaminants. Abatement of Environmental Pollutants: Elsevier; 2020. p. 1-23.

7. Breida M, Younssi SA, Ouammou M, Bouhria M, Hafsi M. Pollution of Water Sources from Agricultural and Industrial Effluents: Special Attention to $\mathrm{NO}_{3}{ }^{-}, \mathrm{Cr}$ (VI), and $\mathrm{Cu}$ (II). Water Chemistry: IntechOpen; 2019.

8. Emami-Meibodi M, Parsaeian M, Amraei R, Banaei M, Anvari F, Tahami S, et al. An experimental investigation of wastewater treatment using electron beam irradiation. Radiation Physics and Chemistry. 2016;125:82-7

9. Ruggaber TP, Talley JW. Enhancing bioremediation with enzymatic processes: a review. Practice Periodical of Hazardous, Toxic, and Radioactive Waste Management. 2006;10(2):73-85.

10. Rao M, Scelza R, Scotti R, Gianfreda L. Role of enzymes in the remediation of polluted environments. Journal of soil science and plant nutrition. 2010;10(3):333-53.

11. Mousavi S, Esmaeili H, Arjmand O, Karimi S, Hashemi S. Biodegradation study of nanocomposites of phenol novolac epoxy/unsaturated polyester resin/egg shell nanoparticles using natural polymers. Journal of Materials. 2015;2015:1-6.

12. Hashemi SA, Mousavi SM, Ramakrishna S. Effective removal of mercury, arsenic and lead from aqueous media using Polyaniline$\mathrm{Fe} 3 \mathrm{O} 4$-silver diethyldithiocarbamate nanostructures. Journal of Cleaner Production. 2019;239:118023.

13. Mousavi S, Hashemi S, Amani A, Moujodi F, Hamedfateh A, Zarei M. Modification of polypropylene-starch blend by eggshell nano-particle, EVA and maleic anhydride to improve biodegradability and thermal properties. Int $\mathrm{J}$ Chem Sci. 2018;15:225.

14. Liu X, Kokare C. Microbial enzymes of use in industry. Biotechnology of microbial enzymes: Elsevier; 2017. p. 267-98.

15. Anbu P, Gopinath SC, Chaulagain BP, Lakshmipriya T. Microbial enzymes and their applications in industries and medicine 2016 Hindawi; 2017.

16. Sheikhy J, Ronaghi A, Karimian N, Zarei M, Mousavi S. Effect of vermicompost and Rhizophagus irregularis fungi on yield, nutrient uptake and chlorophyll content of two wheat cultivars. 2017.

17. Megharaj M, Ramakrishnan B, Venkateswarlu K, Sethunathan N, Naidu R. Bioremediation approaches for organic pollutants: a critical perspective. Environment international. 2011;37(8):136275.

18. Zadeh BS, Esmaeili H, Foroutan R, Mousavi SM, Hashemi SA Removal of $\mathrm{Cd} 2$ from Aqueous Solution using Eucalyptus Sawdust as a Bio-Adsorbent: Kinetic and Equilibrium Studies. Journal of Environmental Treatment Techniques. 2020;8(1):112 8.

19. Goudarzian N, Sadeghi Z, Mousavi SM, Hashemi SA, Banaei N. Chemical constituent and determination of antimicrobial and antifungal activities of Ulva lactuca species obtained from Iranian Gheshm Island. Int J Sci Eng Res. 2017;8:1275-9.

20. Hashemi SA, Mousavi SM, Bahrani S, Ramakrishna S Polythiophene silver bromide nanostructure as ultra-sensitive nonenzymatic electrochemical glucose biosensor. European Polymer Journal. 2020;138:109959.

21. Laino A, Lopez-Zavala AA, Garcia-Orozco KD, CarrascoMiranda JS, Santana M, Stojanoff V, et al. Biochemical and structural characterization of a novel arginine kinase from the spider Polybetes pythagoricus. PeerJ. 2017;5:e3787.

22. Newman J, Peat TS, Richard R, Kan L, Swanson PE, Affholter JA, et al. Haloalkane dehalogenases: structure of a Rhodococcus enzyme. Biochemistry. 1999;38(49):16105-14.

23. Li A, Shao Z. Biochemical characterization of a haloalkane dehalogenase DadB from Alcanivorax dieselolei B-5. PloS one. 2014;9(2):e89144.

24. Copley SD. Microbial dehalogenases: enzymes recruited to convert xenobiotic substrates. Current opinion in chemical biology. 1998;2(5):613-7.

25. Sheehan D, MEADE G, FOLEY VM, DOWD CA. Structure, function and evolution of glutathione transferases: implications for classification of non-mammalian members of an ancient enzyme superfamily. Biochemical journal. 2001;360(1):1-16.

26. Gullner G, Komives T, Király L, Schröder P. Glutathione Stransferase enzymes in plant-pathogen interactions. Frontiers in plant science. 2018;9:1836.

27. Singh RS, Singh T, Pandey A. Microbial enzymes - an overview. Advances in Enzyme Technology: Elsevier; 2019. p. 1-40.

28. Arora PK, Kumar M, Chauhan A, Raghava GP, Jain RK OxDBase: a database of oxygenases involved in biodegradation. BMC research notes. 2009;2(1):67.

29. Tech JET. Investigating the Activity of Antioxidants Activities Content in Apiaceae and to Study Antimicrobial and Insecticidal Activity of Antioxidant by using SPME Fiber Assembly 
Carboxen/Polydimethylsiloxane (CAR/PDMS). Journal of Environmental Treatment Techniques. 2020;8(1):214-24

30. Hajinezhad SAH, Amani AM, Mojtaba S. Investigation the Antioxidant, Antibacterial and Insecticidal Activities of Cuscuta epithymum and Pyrethrum roseum Plants using Polydimethylsiloxane (CAR/PDMS). Journal of Environmental Treatment Techniques. 2019;7(3):234-44.

31. Gheitasi I, Azizi A, Omidifar N, Doustimotlagh AH. Renoprotective Effects of Origanum majorana Methanolic L and Carvacrol on Ischemia/Reperfusion-Induced Kidney Injury in Male Rats. Evidence-Based Complementary and Alternative Medicine. 2020;2020.

32. Rodríguez Couto S, Toca Herrera JL. Industrial and biotechnological applications of laccases: A review. Biotechnology Advances. 2006;24(5):500-13.

33. Mohsenzadeh F, Rad AC, Akbari M. Evaluation of oil removal efficiency and enzymatic activity in some fungal strains for bioremediation of petroleum-polluted soils. Iranian journal of environmental health science \& engineering. 2012;9(1):26.

34. Garcia-Arellano H, Alcalde M, Ballesteros A. Use and improvement of microbial redox enzymes for environmental purposes. Microbial Cell Factories. 2004;3(1):1-3.

35. Omidifar N, Nili-Ahmadabadi A, Gholami A, Dastan D, Ahmadimoghaddam D, Nili-Ahmadabadi H. Biochemical and histological evidence on the protective effects of allium hirtifolium boiss (Persian Shallot) as an herbal supplement in Cadmiuminduced hepatotoxicity. Evidence-based complementary and alternative medicine. 2020;2020.

36. Sanchez S, Demain AL. Chapter 1 - Useful Microbial EnzymesAn Introduction. In: Brahmachari G, editor. Biotechnology of Microbial Enzymes: Academic Press; 2017. p. 1-11.

37. Nigam PS. Microbial enzymes with special characteristics for biotechnological applications. Biomolecules. 2013;3(3):597-611.

38. Singh R, Kumar M, Mittal A, Mehta PK. Microbial enzymes: industrial progress in 21st century. 3 Biotech. 2016;6(2):174.

39. Molina G, Contesini FJ, de Melo RR, Sato HH, Pastore GM. Chapter 11 - $\beta$-Glucosidase From Aspergillus. In: Gupta VK editor. New and Future Developments in Microbial Biotechnology and Bioengineering. Amsterdam: Elsevier; 2016. p. 155-69.

40. Yang H, Li J, Du G, Liu L. Chapter 6 - Microbial Production and Molecular Engineering of Industrial Enzymes: Challenges and Strategies. In: Brahmachari G, editor. Biotechnology of Microbial Enzymes: Academic Press; 2017. p. 151-65.

41. Renneberg R, Berkling V, Loroch V. Chapter 2 - Enzymes: Molecular Supercatalysts for Use at Home and in Industry. In: Renneberg R, Berkling V, Loroch V, editors. Biotechnology for Beginners (Second Edition). Boston: Academic Press; 2017. p. 33 63.

42. Younus H. Oxidoreductases: Overview and Practical Applications. Biocatalysis: Springer; 2019. p. 39-55

43. Martinez AT, Ruiz-Dueñas FJ, Camarero S, Serrano A, Linde D, Lund $\mathrm{H}$, et al. Oxidoreductases on their way to industrial biotransformations. Biotechnology advances. 2017;35(6):815-31.

44. Klebe G. Oxidoreductase Inhibitors. In: Klebe G, editor. Drug Design: Methodology, Concepts, and Mode-of-Action. Berlin, Heidelberg: Springer Berlin Heidelberg; 2013. p. 641-96.

45. Søltoft-Jensen J, Hansen F. New chemical and biochemical hurdles. Emerging technologies for food processing: Elsevier; 2005. p. 387-416

46. Cheriyan S, Abraham ET. Enzymatic bioremediation of cashew nut shell liquid contamination. Journal of hazardous materials. 2010;176(1-3):1097-100.

47. Phale PS, Sharma A, Gautam K. Microbial degradation of xenobiotics like aromatic pollutants from the terrestrial environments. Pharmaceuticals and Personal Care Products: Waste Management and Treatment Technology: Elsevier; 2019. p. 259-78.

48. Fetzner S, Steiner RA. Cofactor-independent oxidases and oxygenases. Applied Microbiology and Biotechnology. 2010;86(3):791-804

49. Martin C, Binda C, Fraaije MW, Mattevi A. Chapter Three - The multipurpose family of flavoprotein oxidases. In: Chaiyen P, Tamanoi F, editors. The Enzymes. 47: Academic Press; 2020. p. 63-86.
50. Dotaniya M, Aparna K, Dotaniya C, Singh M, Regar K. Role of soil enzymes in sustainable crop production. Enzymes in Food Biotechnology: Elsevier; 2019. p. 569-89.

51. Fitzpatrick P. Adv Enzymol Relat Areas Mol Biol. 2000.

52. Di Gennaro P, Bargna A, Sello G. Microbial enzymes for aromatic compound hydroxylation. Applied microbiology and biotechnology. 2011;90(6):1817-27.

53. Massart L, Vercauteren R. Oxygenases and hydroxylases. Annual review of biochemistry. 1959;28(1):527-44.

54. Husain Q, Ullah MF. Biocatalysis: Enzymatic Basics and Applications: Springer Nature; 2019.

55. Xu F. Applications of oxidoreductases: recent progress. Industrial Biotechnology. 2005;1(1):38-50.

56. Gogoi SR. Applications of Oxidoreductases. Oxidoreductase: IntechOpen; 2020

57. May SW. Applications of oxidoreductases. Current opinion in biotechnology. 1999;10(4):370-5.

58. Ahmadi S, Fazilati M, Mousavi SM, Nazem H. Antibacterial/fungal and anti-cancer performance of green synthesized Ag nanoparticles using summer savory extract. Journal of Experimental Nanoscience. 2020;15(1):363-80.

59. Singh P, Singh VK, Singh R, Borthakur A, Madhav S, Ahamad A, et al. Chapter 1 - Bioremediation: a sustainable approach for management of environmental contaminants. In: Singh P, Kumar A, Borthakur A, editors. Abatement of Environmental Pollutants: Elsevier; 2020. p. 1-23.

60. Zamanpour G, Mehrabani-Zeinabad A. An experimental study on bioremediation and photolysis of enrofloxacin. Water science and technology : a journal of the International Association on Water Pollution Research. 2014;70:932-8.

61. Maulin S. Environmental bioremediation: A low cost nature's natural biotechnology for environmental clean-up. Behav Ther. 2014;5(5):266

62. Soleimani M. Bioremediation: an environmental friendly solution for oil contaminated soils. J Bioremed Biodegrad. 2012;3:2155 6199.

63. Azubuike CC, Chikere CB, Okpokwasili GC. Bioremediation techniques-classification based on site of application: principles, advantages, limitations and prospects. World Journal of Microbiology and Biotechnology. 2016;32(11):180.

64. Dangi AK, Sharma B, Hill RT, Shukla P. Bioremediation through microbes: systems biology and metabolic engineering approach. Critical reviews in biotechnology. 2019;39(1):79-98.

65. Iosob G-A, Prisecaru M, Stoica I, Călin M, Cristea TO. Biological remediation of soil polluted with oil products: an overview of available technologies. Universitatea" Vasile Alecsandri" din Bacău. 2016;25(2):89-101

66. Harekrushna S, Kumar DC. A review on: bioremediation. International Journal of Research in Chemistry and Environment 2012;2(1):13-21

67. Kabir E, Kim K-H. A review of some representative techniques for controlling the indoor volatile organic compounds. Asian Journal of Atmospheric Environment. 2012;6(3):137-46.

68. Ali N, Dashti N, Khanafer M, Al-Awadhi H, Radwan S. Bioremediation of soils saturated with spilled crude oil. Scientific reports. 2020;10(1):1-9.

69. Tekere M. Microbial Bioremediation and Different Bioreactors Designs Applied. Biotechnology and Bioengineering: IntechOpen; 2019

70. Mousavi SM, Hashemi SA, Babapoor A, Savardashtaki A, Esmaeili H, Rahnema Y, et al. Separation of Ni (II) from Industrial Wastewater by Kombucha Scoby as a Colony Consisted from Bacteria and Yeast: Kinetic and Equilibrium Studies. Acta Chimica Slovenica. 2019;66(4):865-73.

71. Chaerul M, Tanaka M, Shekdar AV. A system dynamics approach for hospital waste management. Waste management. 2008;28(2):442-9

72. Arutchelvi J, Sudhakar M, Arkatkar A, Doble M, Bhaduri S, Uppara PV. Biodegradation of polyethylene and polypropylene. 2008.

73. Ethica SN, Sabdono A, editors. Bio-remediation potential of hydrolytic bacteria isolated from hospital liquid biomedical waste in Central Java. Proceedings of the 3rd World Congress on New Technologies; 2017. 
74. Ethica SN, Saptaningtyas R, Muchlissin SI, Sabdono A. The development method of bioremediation of hospital biomedical waste using hydrolytic bacteria. Health and Technology. 2018;8(4):239-54. 